\title{
Other Comprehensive Income, Auditor Practice Experience and Audit Pricing
}

\author{
Ziwei Ding \\ School of Management, Jinan University, Guangzhou, China \\ Email: dzw121703@126.com
}

How to cite this paper: Ding, Z.W. (2019) Other Comprehensive Income, Auditor Practice Experience and Audit Pricing. American Journal of Industrial and Business Management, 9, 233-252.

https://doi.org/10.4236/ajibm.2019.91015

Received: December 29, 2018

Accepted: January 20, 2019

Published: January 23, 2019

Copyright $\odot 2019$ by author(s) and Scientific Research Publishing Inc. This work is licensed under the Creative Commons Attribution International License (CC BY 4.0).

http://creativecommons.org/licenses/by/4.0/

\begin{abstract}
The audit pricing problem has always been the focus of academic research. Based on the relevant research of scholars at home and abroad, based on the audit demand theory and the high-level echelon theory, this paper selects the data of A-share listed companies in Shanghai and Shenzhen from 2011 to 2017 as the research sample, and deeply analyzes the relationship among other comprehensive income, auditor practice experience and audit pricing. The study found that: 1) When other conditions remain unchanged, other comprehensive income is positively correlated with audit pricing, and the risk brought by other comprehensive income and the increase of audit cost make auditors need corresponding compensation. 2) When other conditions remain unchanged, other comprehensive income is positively correlated with audit pricing. Auditors with rich experience in providing audit services can make audit clients feel higher audit quality and obtain audit premium. 3) When other conditions remain unchanged, the auditor's practice experience will weaken the positive correlation between other comprehensive income and audit pricing. The experienced auditors are more accurate in interpreting and judging other comprehensive income information, so the risk assessment will also become more reasonable and targeted to carry out further audit procedures, so that the positive relationship between other comprehensive income and audit pricing is weakened to some extent. This research further enriches the relevant theoretical research on audit pricing and provides relevant research basis for audit practice.
\end{abstract}

\section{Keywords}

Audit Pricing, Other Comprehensive Income, Auditor Practice Experience

\section{Introduction}

Audit pricing has always been a hot topic in the field of auditing research at 
home and abroad. In December 2001, China Securities Regulatory Commission issued the "Contents and Formats for Information Disclosure of Companies That Offer Securities to the Public No. 2-Contents and Formats of Annual Reports (Revised 2001)" and "Company Information on Public Offering of Securities". The policy document of Disclosure Specification Q \& A No. 6-Payment of Accounting Firms and Their Disclosures requires that listed companies must disclose audit fees in their financial reports. China has also become a country that has explicitly required listed companies to disclose audit fees after the United States, the United Kingdom, Australia and Hong Kong and other countries and regions. After the mandatory disclosure of the audit fees of listed companies, it is possible to obtain more empirical evidence from the securities market about audit pricing, which provides an opportunity for relevant academic research in China's academic circles, and relevant research is also enriched.

Audit pricing is an attestation service fee charged by an accounting firm to provide audit services to the audited entity. It includes all relevant costs invested by the auditor in the process of providing audit services, as well as necessary risk compensation and profit compensation. Audit service is different from other commodities, and it is difficult to price through market circulation. China's audit market also lacks a unified and reasonable pricing mechanism for a long time. Therefore, the accounting fees of China's accounting firms vary greatly, and the audit market pricing is uneven. Reasonable audit pricing plays an important role in improving the quality of audit services and the standardized development of the CPA profession. The scientific and reasonable audit pricing can guarantee the auditor's income, attract more talents to join the auditing industry, and stay in the auditing service industry to ensure that the auditors have sufficient professional competence; on the other hand, they can ensure that the auditors are doing due diligence and investing sufficient audit resources in implementing specific audit procedures which can further improve the quality of audit work, and will have an important positive impact on the future development of the audit service industry.

With the continuous development of the market economy and the securities market, the company's business form has become more complicated. The traditional profit and loss recognition model based on the historical cost principle is difficult to comprehensively and truly reflect the changes in the company's actual value and the potential risks. In this context, in order to enable the company's financial information to objectively and accurately reflect its financial situation and various complex economic operations, and provide useful information for financial statement users to make relevant decisions, the content and form of improving financial reports is very necessary. As early as 1997, the International Accounting Standards Board (IASC) issued the International Accounting Standards No. 1-Presentation of Financial Statements, which explicitly requires listed companies to disclose in the financial statements that they are not included in profit or loss but are included in the owner's equity' gains and losses. In 2007, the International Accounting Standards Board (IASB) issued a revised 
version of the International Accounting Standards No. 1-Presentation of Financial Statements, and clarified the main components of other comprehensive income, and officially changed the income statement into comprehensive income. The table clarifies the specific disclosure requirements. In July 2013, the International Accounting Standards Board (IASB) issued a comprehensive review of the "Review of the Financial Reporting Conceptual Framework" to conceptually discuss other comprehensive income presentation and disclosure issues and establish corresponding concepts frame.

Taking into account the importance of other comprehensive income information and meeting the needs of economic development, China's disclosure of financial reports has also continuously put forward new requirements. In June 2009, China's Ministry of Finance issued the "Enterprise Accounting Standards Interpretation No. 3" policy document, which first clarified the relevant content of "other comprehensive income" and forced the company to increase "under the income statement" under the income statement. Other comprehensive income items and "total comprehensive income" items are presented. In January 2014, China's Ministry of Finance issued a revised version of the "Accounting Standards for Business Enterprises No. 30-Presentation of Financial Statements", which provides more detailed provisions on the presentation and disclosure of "other comprehensive income" items. Other comprehensive income is classified into two categories: "Other comprehensive income items that cannot be reclassified into profit or loss in subsequent accounting periods" and "Other comprehensive income items that will be reclassified into profit or loss in the future accounting period when the specified conditions are met". It can be seen that other comprehensive income information disclosure issues have received more and more attention.

Other comprehensive income is recognized, measured, recorded and reported as unrealized gains and losses. Overcoming the traditional accounting methods only reflects past events and does not reflect the shortcomings of the future. The financial report of the enterprise not only reflects the realized profit and loss in the current period, but also reflects the current period. The acquisition but not yet realized the profit and loss situation further enhances the transparency of the financial information of the enterprise and reflects the more real and comprehensive financial performance of the enterprise. At the same time, due to the complexity of other comprehensive income accounting measures, low sustainability and high volatility, and the adoption of fair value measurement, it contains more management subjective judgment. Dan Dhaliwal (1999) found that other comprehensive income component information will bring more noise to the financial data of the enterprise. Due to its complexity and other characteristics, there is a greater risk of interpreting and analyzing it [1]. In the actual auditing process, the auditor will inevitably invest more audit resources and implement more auditing procedures to reduce the audit risk to an acceptable low level, taking into account the complexity of other comprehensive benefits. It will inevitably affect the audit pricing behavior. 
Most of the research on the factors affecting audit pricing focuses on the level of accounting firms and the level of audited entities, and often ignores the impact of auditor's individual characteristics on audit pricing. The difference between the individual characteristics of the auditor will affect the auditor's cognition and behavior, as the specific executor of the audit work, which will inevitably have an impact on the quality of the audit work. The individual characteristics of the auditor include gender, age, education, professional background and professional experience. However, we believe that the most perceptible individual characteristics of management are the auditor's practice experience. The more experienced the auditor's practice experience, the more the auditor's experience is. The accumulation of practical knowledge and greater professional competence, analytical problems, and problem-solving skills will enhance the perception of auditing customer quality and thus affect audit pricing. Of course, experienced auditors have strong ability to practice, and the interpretation and judgment of other comprehensive income information may be more accurate, which will further affect the results of their risk assessment and the allocation of audit resources.

This paper selects China's 2011-2017 A-share listed companies in Shanghai and Shenzhen as research samples, collects and collates relevant data, and establishes multiple regression models to investigate whether other comprehensive income and auditor's practice experience will have a significant impact on audit pricing. And further verify and analyze whether the auditor's practice experience will have an impact on the relationship between other comprehensive income and audit pricing, thus enriching relevant theoretical research and providing reference recommendations for audit practice.

The research framework of this paper is shown in Figure 1.

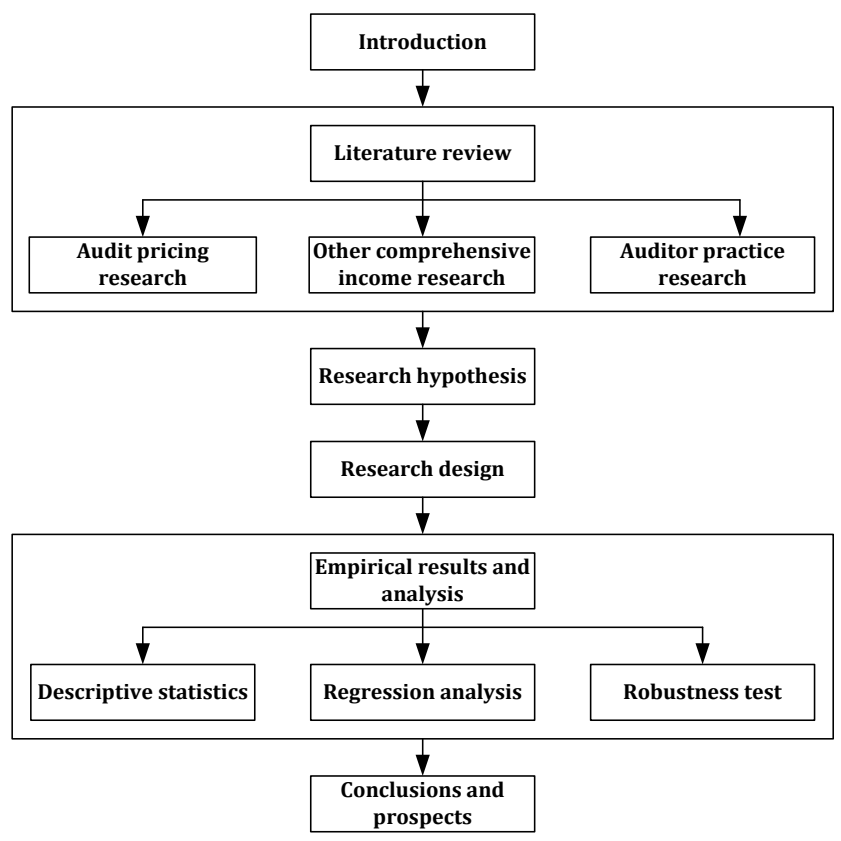

Figure 1. Research framework. 


\section{Literature Review}

\subsection{Audit Pricing Research}

Simunic (1980) first used the multiple regression model to carry out empirical research on audit pricing [2]. Since then, scholars have continuously enriched and perfected the classical audit pricing model proposed by Simunic, so there are many related research results. In this paper, the research on the factors affecting audit pricing can be divided into two aspects: the level of the audited unit and the level of the accounting firm. The research results at home and abroad are reviewed.

1) Audited entity level

The larger the scale of the audited entity, the higher the complexity of the business, which generally means that the resources invested by the auditor and the audit workload are increased, which may increase the audit fees. Simunic (1980) used the audit data of US listed companies, and empirical research found that the size of the company and the level of business complexity can significantly affect audit fees. Francis (1984) used Australian audit market data to test the revised Simunic audit pricing model. It also found that the size of the assets of the audited entity and the complexity of the business measured by the number of holding subsidiaries significantly affected the audit fees [3]. Firth (1985) used the data from the New Zealand audit market to draw conclusions that were basically consistent with Simunic (1980) and Francis (1984) [4].

Regarding the impact of the company's risk level on audit pricing, scholars mainly discuss the risks related to the audited units and the management earnings management behavior. Bell et al. (2001) analyzed the relationship between the audited unit's operating risk and the audit fees perceived by the auditor, and found that the auditor's audited unit with high operational risk will increase the audit duration, but the unit audit fee will not occur. It is that the auditor obtains corresponding risk compensation by extending the working hours and increasing the audit fees [5]. Abbott et al. (2006) selected the data of 429 listed companies in the United States in 2000 as a sample, empirically tested the relationship between earnings management behavior and audit fees, and found that the audited unit is increasing earnings audit fees and negative Earnings management will reduce audit fees, that is, positive earnings management behavior will give auditors greater audit risk than negative earnings management behavior [6].

Some scholars have used the UK audit market data to empirically test the relationship between the effectiveness of the audit committee and the audit fees. The study found that the existence of the audit committee would significantly increase the audit fees associated with the size of the company, because the audit committee's quality of the audit report. There are higher requirements to ensure that the auditor has sufficient audit time, which leads to an increase in audit fees. Carcello et al. (2002) used Fortune 1000 companies to explore the relationship between board characteristics (independence, diligence, and professional competence) and auditor fees, and found that board meetings that were more inde- 
pendent, more diligent, and more professional. Higher audit quality is required, so auditors need to invest more audit resources to increase audit fees [7].

2) Audit firm level

Domestic and foreign scholars have not reached a consensus conclusion on the relationship between the size of accounting firms and audit fees. Some scholars believe that the size of accounting firms is not significantly related to audit fees. Simunic (1980) based on the classic model of audit pricing, found that the scale of accounting firms did not produce significant audit fees, whether in small-scale clients or large-scale clients' influences. Using data from New Zealand listed companies. Firth (1985) also found that the size of an accounting firm does not have a significant impact on audit fees.

Craswell et al. (1995) used a sample of 1484 listed companies in Australia to estimate the audit fee premium that the "Top8" accounting firms with more industry expertise can bring. The empirical research found that the "Top8" of industry expertise It has a $34 \%$ audit fee premium over other accounting firms and considers industry expertise to be a dimension of high quality auditing requirements and the basis for providing differentiated auditing services [8]. DeFond et al. (2000) based on the data of 348 listed companies in Hong Kong, the research found that the industry expertise makes the audit fees of the "six big" and "non-six big" accounting firms different, and the "six big" with industry expertise clearly gained more audit premiums [9]. Carson and Fargher (2007) used Australian listed company data to find that accounting firms with industry expertise charge higher audit fees for industry leaders because they often require higher quality audit services [10].

Many scholars have explored the impact of firm changes on audit pricing. Simon and Francis (1988) used the data of listed companies in the United States from 1979 to 1984. After the change of the firm, the audit fee of the first auditor of the new auditor was $24 \%$ lower than the normal level. The second and third year audit fees were collected. It is $15 \%$ lower than the normal level and returns to the normal level in the fourth year, indicating that there are low-cost passengers in the change process [11]. Yanzhen Song and Dequan Yin (2005) used the data of listed companies changed by the firm in 2002-2003, and found that for the companies with strong earnings management motives, the new auditors will charge higher audit fees to obtain risk compensation. For companies with limited ability to pay, the new auditor will charge a lower audit fee [12].

\subsection{Other Comprehensive Income Research}

Regarding price correlation, Dhaliwal et al. (1999) used the empirical data of US listed companies in 1994-1995 to believe that the stock price correlation of net profit is stronger than the stock price correlation of other comprehensive income, and the disclosure of international accounting standards requires disclosure of other the need for a comprehensive income project raises questions. Landsman et al. (2011) set the equity market price as the dependent variable and 
draw on the Ohlson (1995) valuation model. The study found that other comprehensive income is not related to the stock price, and that investors believe that other comprehensive income versus stock price. The role of the assessment is temporary [13]. Goncharov et al. (2011) found that through the data research of listed companies in 16 European countries, although other comprehensive incomes have stock price correlation, their correlation is lower than net profit [14].

Regarding the relevance of compensation, Cheng et al. (1993) used the data of listed companies in the United States from 1972 to 1989 to study the correlation between operating income, net income and comprehensive income and stock returns, and found that operating income and net income were more incremental. Information, and the correlation between comprehensive income and stock returns is not as good as operating income and net income [15]. Dhaliwal et al. (1999), drawing on the test method of Vuong (1989), found that the business type of enterprises affects the interpretation of stock returns by comprehensive income. In non-financial enterprises, the correlation between comprehensive income and stock returns is lower than net income. In financial enterprises, the ability of comprehensive income to interpret stock returns is much higher than net income.

Regarding forecasting ability, Dhaliwal et al. (1999) empirically tested the ability of other comprehensive income to predict future earnings and cash flow, and compared the net profit as a reference, and found that the forecasting ability of other comprehensive income is relatively weak. Barton et al. (2010) also believe that the ability of comprehensive income to predict future performance is indeed limited [16]. Different from the above research, Biddle et al. (2006) believe that the comprehensive income forecasting ability of future earnings is stronger than the net profit, and it is also found that the management of the company will use the characteristics of other comprehensive income unrealized to conduct earnings management behavior [17]. Kanagaretnam et al. (2009) analyzed the ability of comprehensive income and net profit to predict future earnings and future cash flows, respectively. The study found that the comprehensive income forecasting ability of future cash flow is significantly stronger than the net profit indicator. But for the future, the ability to predict returns is weaker than the net profit indicator [18].

Risk correlation explores the relationship between time series fluctuations in financial statements and fluctuations in stock prices or time series of returns. Other comprehensive income items are more complex than the net profit items, and are temporary and volatile. Therefore, the financial information contained in other comprehensive income will affect investors' assessment of corporate risk (Hirst et al., 1998) and will affect investment decisions [19]. Maines et al. (2000) explored whether the presentation of comprehensive income would affect the processing and evaluation of comprehensive income information by non-professional investors, and whether it would affect investors' assessment of 
company stock risk [20]. Maines et al. (2000) found that regardless of whether the comprehensive income information is presented in the income statement or the owner's equity table, investors can accurately assess the risk of fluctuations in the unrealized gains and losses of the company's available-for-sale securities, including in the income statement. In the presentation, investors are more sensitive to the risk of unrealized gains and losses on available-for-sale securities than when presented in the owner's equity statement. Comprehensive income information can help investors assess the risk situation of the company. Khan et al. (2014) used the US non-financial company data from 2005 to 2010. The study found that the volatility of comprehensive income after adjusting for asset revaluation is still stronger than net income, but there is no evidence that the volatility of comprehensive income and stock return volatility the correlation between [21].

\subsection{Auditor Practice Research}

The auditor's practice experience is the professional knowledge and skills that he has accumulated in the practice of auditing. The longer the auditor's practice period is, the more familiar he is with the auditing matters and the auditing process, and the accumulated auditing experience is also richer. Most of the existing literature focuses on the impact of auditor practice on the quality of audit work. Libby et al. (1990) experimental studies have shown that auditors' experience in the practice process can help them more accurately identify misstatements, underreports, and even fraudulent practices in auditing clients' financial reports [22]. Weifang Han (2016) selected the data of listed companies in China from 2002 to 2012 as a sample. The study found that the number of signatures before the accounting year of the auditing accountant was significantly positively correlated with the audit fees, that is, the more the number of signatures, the higher the audit fees [23]. Xiaoke Wang et al. (2016) used the 1998-2009 data of listed companies in China to explore the impact of auditors' personal experience on audit quality. The study found that under the control of company characteristics and firm characteristics, the auditor's personal experience and audit quality are positive. Relevant, that is, the richer the audit experience, the higher the audit quality provided by the auditor [24]. Jian Zhang and Chunyan Wei (2016) selected the data of China's Shanghai and Shenzhen A-shares listed companies in 2009-2014, which also confirmed that the auditor's practice experience can have a positive impact on audit quality, and due to the existence of legal risks, this the relationship will be more obvious [25].

\section{Research Hypothesis}

\subsection{Other Comprehensive Income and Audit Pricing}

Other comprehensive income reflects the information of the company's future cash flow and future earnings to a certain extent, providing richer, timely and forward-looking information for the reporting users' investment management 
decisions, which helps to improve the usefulness of financial information decision-making. However, because other comprehensive income information has characteristics of high volatility and uncertainty, low sustainability, and many items contain the subjective judgment of management, it will bring more noise to the financial statement information of the enterprise. It is also difficult to interpret and judge other comprehensive income information, and thus has a large audit risk.

The volatility and complexity of other comprehensive incomes will affect the auditor's risk assessment and increase the inherent risk of auditing. Therefore, the auditor needs to consider the impact of this factor when collecting audit fees to obtain the corresponding risks and cost compensation (Huang \& Lin, 2016) [26]. Auditor pricing is mainly influenced by audit risk and audit cost. Simunic (1980), Wei Pan, and Qingquan Xin (2003) believe that audit risk is indeed an important factor in audit pricing. The higher the audit risk of the audited entity, the greater the litigation risk faced by the auditor, and the more compensation is required, so the audit fee will be increased (Chun Cai et al., 2015) [27] [28].

The impact of other comprehensive income on audit pricing is mainly reflected in two aspects. First, other comprehensive income reflects the unrealized profit and loss of the enterprise. The information is highly volatile and complex, so the auditor interprets and analyzes it. There is a great risk. Second, the fair value measurement attribute of other comprehensive income will contain more management's subjective judgments and estimates, which may lead to more management earnings management behavior (Kezhi Yang, 2016) [29], and may also as a result of the estimation bias of accounting measurement, the risk faced by the auditor will be further improved, and the audit fee will be increased. According to the insurance theory of auditing requirements, when the audited entity has a high audit risk, it must pay a higher audit fee to obtain the corresponding insurance value. Therefore, this paper proposes the hypothesis $\mathrm{H} 1$ :

H1: When other conditions are unchanged, other comprehensive income is positively correlated with audit pricing.

\subsection{Auditor Practice Experience and Audit Pricing}

In recent years, scholars at home and abroad have gradually paid attention to the personal characteristics of auditors and whether they will have an impact on the professional judgment and decision-making of auditors. Hambrick et al. (1984) proposed a high-level echelon theory based on demographic characteristics, and found that managers with different gender, age, experience and other characteristics will have a great impact on the decision-making behavior of enterprises [30]. As the executor and completer of the audit work, the auditor has important auditing responsibilities. Therefore, it is not difficult to infer that the characteristics of the auditor's personal aspects will inevitably affect the judgment of the financial status and operating results of the audited company. The assessment of audit risk will affect the audit fees charged by the auditor to the audited compa- 
ny to a certain extent.

The auditor's ability to practise, first of all, accumulates specialized knowledge in the intellectual phase, and then constantly improves in practice. It is generally believed that the longer the auditor's practice period is, the more familiar he is with the auditing matters and the auditing process, and the accumulated auditing experience is also richer. Libby et al. (1990) have shown that auditors' experience in the practice process can help them more accurately identify misstatements, underreports, and even fraudulent practices in auditing clients' financial reports. Weifang Han (2016) found that the number of signatures before the accounting year of the review accountant is significantly positively correlated with the audit fees, that is, the greater the number of signatures, the higher the audit fees. Xiaoke Wang et al. (2016) studied the impact of auditor's personal experience on audit quality. In the case of controlling company characteristics and firm characteristics, the auditor's personal experience is positively related to the audit quality, that is, the richer the audit experience, the auditor provides. The higher the quality of the audit. Jian Zhang and Chun Wei (2016) also confirmed that auditor practice experience can have a positive impact on audit quality, and this relationship will become more apparent due to the existence of legal risks.

On the one hand, more experienced auditors can avoid more interference, and can make more accurate professional judgments on the problems existing in the audit, so that audit clients can perceive higher audit quality, and audit clients are willing to Paying higher audit fees to hire experienced auditors. On the other hand, in order to retain audit talents and make up for the cost of labor, auditors also charge audit clients a higher audit fee. Therefore, this paper proposes the hypothesis $\mathrm{H} 2$ :

$\mathrm{H} 2$ : When other conditions are unchanged, auditor practice experience is positively correlated with audit pricing.

\subsection{Other Comprehensive Income, Auditor Practice Experience and Audit Pricing}

Other comprehensive income items contain more complex content, and the implied audit risk is also higher. Therefore, it is inevitable for the general auditor to blindly increase the input of audit resources and expand the scope of testing for control tests and substantive procedures. As a result, the audit cost is increased, and the audited unit is charged a higher audit fee (Jixun Zhang et al., 2005) [31]. Due to the professionalism and comprehensiveness of other comprehensive income information, different auditors will inevitably bring different interpretations due to differences in their experience and knowledge structure, which will inevitably affect the planning, implementation and development of further audit work.

For auditors with more experienced experience, their accumulated expertise in audit practice will inevitably make them more mature in judging relevant audit matters and reduce the interference caused by some irrelevant information 
(Shelton, 1999) [32]. Although other comprehensive income information is more complicated and contains more content, not every component will contain a large audit risk, and the auditor needs to blindly implement more audit procedures. On the contrary, the richer the auditor's practice experience, the more accurate the interpretation and judgment of other comprehensive income information, the more reasonable the evaluation of audit risk will be, so the actual audit work will be carried out more specifically, and the appropriate investment will be put in place. Audit resources do not necessarily lead to an increase in audit fees, and reduce audit risk to a reasonably low level. Therefore, this paper proposes the hypothesis $\mathrm{H} 3$ :

H3: When other conditions remain unchanged, auditors' practice experience will weaken the positive relationship between other comprehensive income and audit pricing.

\section{Research Design}

\subsection{Data Source}

This paper selects China's 2011-2017 A-share listed companies in Shanghai and Shenzhen as the research object, and treats the research samples as follows: 1) Excluding ST and ${ }^{\star}$ ST companies in abnormal trading status; 2) Excluding financial insurance Company sample; 3 ) Excluding company samples with missing research variable data. The data of this research object mainly comes from Guotaian database (http://www.gtarsc.com), and the auditor's practice data is manually collected through the official website of China Institute of Certified Public Accountants (http://www.cicpa.org.cn/). And mainly use Excel2016 and Stata12.0 software to process and analyze the data, and perform Winsorize processing on the main continuous variables by $1 \%$ and $99 \%$, to eliminate the influence of outliers, and finally obtain 13,978 sample observations.

\subsection{Variable Definitions}

The study variables in this paper are defined as follows (Table 1).

\subsection{Model Construction}

Based on the research of Huang and Lin (2016), this paper applies the panel data fixed effect model and builds the model (1) to test $\mathrm{H} 1$ and $\mathrm{H} 2$ to examine the impact of other comprehensive income and auditor's practice experience on audit pricing.

$$
\begin{aligned}
\text { Lnfee }= & \alpha_{0}+\alpha_{1} \mathrm{OCI}+\alpha_{2} \text { Experience }+\alpha_{3} \mathrm{ROA}+\alpha_{4} \mathrm{Rec}+\alpha_{5} \mathrm{Inv}+\alpha_{6} \mathrm{Cur} \\
& +\alpha_{7} \mathrm{Size}+\alpha_{8} \mathrm{Mb}+\alpha_{9} \text { Level }+\alpha_{10} \mathrm{Loss}+\alpha_{11} \text { Top10 } \\
& +\alpha_{12} \text { Opinion }+\alpha_{13} \operatorname{Big} 4+\sum \text { Year }+\sum \text { Industry }+\varepsilon
\end{aligned}
$$

This paper examines $\mathrm{H} 3$ by constructing a model (2) to examine the impact of auditor practice on the relationship between other comprehensive benefits and audit pricing. 
Table 1. Variable definition table.

\begin{tabular}{|c|c|c|c|}
\hline Variable Type & Name & Symbol & Variable Definition \\
\hline $\begin{array}{l}\text { Interpreted } \\
\text { variable }\end{array}$ & Audit pricing & Lnfee & Natural logarithm of annual audit fees \\
\hline \multirow{2}{*}{$\begin{array}{l}\text { Explanatory } \\
\text { variables }\end{array}$} & Other comprehensive income & OCI & Natural logarithm of the absolute value of other comprehensive income \\
\hline & Auditor practice experience & Experience & Average number of years of signed auditor practice \\
\hline \multirow{13}{*}{ Control variable } & \multirow{9}{*}{ Audited unit } & ROA & Return on assets, annual net profit divided by average total assets \\
\hline & & $\operatorname{Rec}$ & $\begin{array}{l}\text { Accounts receivable ratio, total accounts receivable at the end of the period divided } \\
\text { by total assets at the end of the period }\end{array}$ \\
\hline & & Inv & $\begin{array}{l}\text { Inventory share, total inventory at the end of the period divided by total assets at } \\
\text { the end of the period }\end{array}$ \\
\hline & & Cur & $\begin{array}{l}\text { Current ratio, total liquidity at the end of the period divided by total current } \\
\text { liabilities at the end of the period }\end{array}$ \\
\hline & & Size & Company size, natural logarithm of total assets at the end of the period \\
\hline & & $\mathrm{Mb}$ & $\begin{array}{l}\text { Market value book ratio, ending market value divided by book value of total assets } \\
\text { at the end of the period }\end{array}$ \\
\hline & & Level & $\begin{array}{l}\text { Asset-liability ratio, total liabilities at the end of the period divided by total assets at } \\
\text { the end of the period }\end{array}$ \\
\hline & & Loss & Loss situation, if the net profit is less than 0 , take 1 ; otherwise take 0 \\
\hline & & Top10 & $\begin{array}{l}\text { The concentration of equity, the sum of the shareholding ratio of the top ten } \\
\text { shareholders }\end{array}$ \\
\hline & \multirow[t]{2}{*}{ Audit firm characteristics } & Opinion & $\begin{array}{l}\text { The type of audit opinion, if it is a non-standard audit opinion, take } 1 \text {; otherwise, } \\
\text { take } 0\end{array}$ \\
\hline & & Big4 & Virtual variables, if the audit of the "big4" accounting firm takes 1 , otherwise take 0 \\
\hline & Annual variable & Year & Annual dummy variable \\
\hline & Industry variable & Industry & Industry dummy variable \\
\hline
\end{tabular}

$$
\begin{aligned}
\text { Lnfee }= & \alpha_{0}+\alpha_{1} \mathrm{OCI}+\alpha_{2} \text { Experience } * \mathrm{OCI}+\alpha_{3} \text { Experience }+\alpha_{4} \mathrm{ROA} \\
& +\alpha_{5} \mathrm{Rec}+\alpha_{6} \mathrm{Inv}+\alpha_{7} \mathrm{Cur}+\alpha_{8} \mathrm{Size}+\alpha_{9} \mathrm{Mb}+\alpha_{10} \text { Level }+\alpha_{11} \text { Loss } \\
& +\alpha_{12} \text { Opinion }+\alpha_{13} \text { Top1 } 0+\alpha_{14} \mathrm{Big} 4+\sum \text { Year }+\sum \text { Industry }+\varepsilon
\end{aligned}
$$

\section{Empirical Results and Analysis}

\subsection{Descriptive Statistics}

Table 2 reports the descriptive statistics of the variables studied in this paper. From the explanatory variable Lnfee, the sample company's audit fee averaged 13.68 , the median was 13.59 , and the average audit fee was greater than the median, indicating that most of the listed companies paid audit fees below average, audit fees The higher the situation occurs in a small number of companies. The average value of the explanatory variable OCI is 7.58 , the standard deviation is 7.68 , and the ratio of the standard deviation to the average is greater than 1 , indicating that the other comprehensive income data disclosed by different listed companies in China differs greatly. The average value of the explanatory variable Experience is 15.54 , and the median is 15.46 . The difference between the mean 
Table 2. Descriptive statistics.

\begin{tabular}{ccccccccc}
\hline Variable & N & Mean & Sd & Min & P25 & P50 & P75 & Max \\
\hline Lnfee & 13,978 & 13.68 & 0.727 & 9.21 & 13.22 & 13.59 & 14.01 & 18.06 \\
OCI & 13,978 & 7.58 & 7.677 & -4.605 & 0 & 8.494 & 14.98 & 19.82 \\
Experience & 13,978 & 15.54 & 3.704 & 6.96 & 12.96 & 15.46 & 18.14 & 24.36 \\
ROA & 13,978 & 0.0445 & 0.0547 & -0.156 & 0.0153 & 0.0388 & 0.071 & 0.224 \\
Rec & 13,978 & 0.114 & 0.102 & 0 & 0.03 & 0.0898 & 0.169 & 0.461 \\
Inv & 13,978 & 0.154 & 0.147 & 0 & 0.06 & 0.116 & 0.191 & 0.749 \\
Cur & 13,978 & 2.63 & 2.982 & 0.261 & 1.127 & 1.672 & 2.849 & 19.46 \\
Size & 13,978 & 22.06 & 1.293 & 19.48 & 21.11 & 21.88 & 22.8 & 25.95 \\
Mb & 13,978 & 2.382 & 2.235 & 0.201 & 0.942 & 1.708 & 3.008 & 12.99 \\
Level & 13,978 & 0.426 & 0.216 & 0.0462 & 0.25 & 0.416 & 0.591 & 0.92 \\
Loss & 13,978 & 0.0823 & 0.275 & 0 & 0 & 0 & 0 & 1 \\
Top10 & 13,978 & 0.585 & 0.156 & 0.22 & 0.474 & 0.595 & 0.708 & 0.903 \\
Opinion & 13,978 & 0.0263 & 0.16 & 0 & 0 & 0 & 0 & 1 \\
Big4 & 13,978 & 0.0487 & 0.215 & 0 & 0 & 0 & 0 & 1 \\
\hline
\end{tabular}

and the median is small, and the data distribution of each quantile is also reasonable.

In terms of control variables, the ROA of the listed company's return on assets is $4.45 \%$, the median is $3.88 \%$, the highest return on assets is $22.40 \%$; the account receivable ratio is $11.40 \%$, and the median is only $8.98 \%$, indicating that most of the listed companies accounted for a lower proportion of total assets; the inventory ratio of Inv was $15.40 \%$, the median was $11.60 \%$, and the highest inventory was $74.90 \%$; the current ratio of Cur was 2.63, with a median of 1.67 and a $75 \%$ quantile of 2.85, indicating that most listed companies have lower current ratios; the company's size average is 22.06 , the median is 21.88 , and the other quantiles are between The difference is also small, which indicates that the difference between the assets of China's listed companies is relatively small; the market-to-book ratio is 2.38 , the median is 1.71 ; the average value of the asset-liability ratio is $42.6 \%$. The median is $41.6 \%$, the asset-liability ratio is up to $92 \%$, and the Loss average is $8.23 \%$, indicating that there are fewer losses in listed companies in China; the top $10 \%$ of equity concentration is $58.5 \%$, the median is $59.5 \%$, the sum of the highest shareholding ratio of the top ten shareholders It is $90.3 \%$; the average Opinion of the audit opinion type is $2.63 \%$, which indicates that there are fewer cases of non-standard audit opinions issued by listed companies in China. The average value of Big4 is only $4.87 \%$, indicating that the market share of China's Big4 accounting firms is relatively low.

\subsection{Regression Analysis}

Table 3 reports the regression results for each model. The regression results of 
Table 3. Multiple regression results.

\begin{tabular}{|c|c|c|}
\hline Variable & Model (1) & Model (2) \\
\hline \multirow[t]{2}{*}{ OCI } & $0.00276^{* * *}$ & $0.00643^{* * *}$ \\
\hline & 5.103 & 4.21 \\
\hline \multirow[t]{2}{*}{ Experience $\times$ OCI } & & $-0.000234^{* *}$ \\
\hline & & -2.570 \\
\hline \multirow[t]{2}{*}{ Experience } & $0.00245^{\star * *}$ & $0.00428^{* * *}$ \\
\hline & 3.062 & 3.997 \\
\hline \multirow[t]{2}{*}{$\mathrm{ROA}$} & 0.0512 & 0.0468 \\
\hline & 0.731 & 0.667 \\
\hline \multirow[t]{2}{*}{$\operatorname{Rec}$} & 0.0716 & 0.075 \\
\hline & 1.3 & 1.362 \\
\hline \multirow[t]{2}{*}{ Inv } & 0.0274 & 0.0286 \\
\hline & 0.694 & 0.726 \\
\hline \multirow[t]{2}{*}{ Cur } & -0.000229 & -0.000335 \\
\hline & -0.169 & -0.248 \\
\hline \multirow[t]{2}{*}{ Size } & $0.340^{* * *}$ & $0.340^{\star * *}$ \\
\hline & 48.14 & 48.19 \\
\hline \multirow[t]{2}{*}{$\mathrm{Mb}$} & $0.0107^{* * *}$ & $0.0107^{* * *}$ \\
\hline & 5.723 & 5.767 \\
\hline \multirow[t]{2}{*}{ Level } & -0.00866 & -0.0103 \\
\hline & -0.309 & -0.366 \\
\hline \multirow[t]{2}{*}{ Loss } & $0.0331^{* * *}$ & $0.0330^{* * *}$ \\
\hline & 3.225 & 3.214 \\
\hline \multirow[t]{2}{*}{ Top10 } & $0.168^{* * *}$ & $0.169^{* * *}$ \\
\hline & 5.211 & 5.246 \\
\hline \multirow[t]{2}{*}{ Opinion } & $0.0761^{* * *}$ & $0.0765^{\star * *}$ \\
\hline & 4.661 & 4.687 \\
\hline \multirow[t]{2}{*}{ Big4 } & $0.154^{\star \star \star}$ & $0.153^{\star * *}$ \\
\hline & 5.099 & 5.056 \\
\hline \multirow[t]{2}{*}{ Constant } & $6.113^{* * *}$ & $6.076^{* * *}$ \\
\hline & 39.46 & 39.07 \\
\hline Year & Yes & Yes \\
\hline Industry & Yes & Yes \\
\hline R-squared & 0.538 & 0.539 \\
\hline $\mathrm{N}$ & 13,978 & 13,978 \\
\hline
\end{tabular}

T-statistics in parentheses: ${ }^{* * *} \mathrm{p}<0.01,{ }^{* *} \mathrm{p}<0.05,{ }^{*} \mathrm{p}<0.1$.

model (1) show that other comprehensive incomes have a significant positive correlation with audit pricing at the $1 \%$ significance level, which indicates the 
complexity, volatility and uncertainty of other comprehensive income items, and still exists. The subjective estimation of more management will provide space for management earnings management behavior (Yang Kezhi, 2016), and the risks faced by auditors will be further enhanced, so that auditors need to perform more auditing procedures and invest more audit resources. The company will be required to charge a higher audit fee as a compensation for risk and cost, verifying H1. The empirical results of the model (1) also show that the auditor's practice experience is significantly positively correlated with the audit pricing at the $1 \%$ significance level, which verifies $\mathrm{H} 2$, which indicates that the longer the auditor's years of practice, the accumulated experience and knowledge gained. During the execution of the audit business, it can make more accurate and professional judgments on relevant audit matters and problems, so that audit clients perceive higher audit quality and thus obtain higher audit fees.

In the model (2) regression results, other comprehensive incomes are significantly positive with audit pricing at $1 \%$ significance level, and the balance between other comprehensive income and auditor's practice experience is negative at $5 \%$ significance level and audit pricing. Significant, this shows that the auditor practice experience does weaken the positive relationship between other comprehensive income and audit pricing. Auditors with different professional experience will have different interpretations of other comprehensive incomes. For experienced auditors, they can significantly reduce the interference of certain information, and the judgment of audit risk matters is more precise and mature, so it will be more Targeted audit work has been carried out, which has weakened the positive impact of other comprehensive income on audit pricing to some extent.

From the control variables, in model (1) and model (2), ROA, accounts receivable ratio Rec and inventory ratio Inv are positively correlated with audit pricing, but not significant enough, and did not bring audit The cost is significantly improved; the current ratio Cur is negatively correlated with the audit pricing, mainly because the higher the corporate turnover ratio and the stronger the solvency, the lower the risk faced by the auditor; the size of the company size is $1 \%$ significant. The level is significantly positively correlated with the audit pricing. The higher the company scale, the more complicated the economic business is. The auditors need to invest more resources. Therefore, it is necessary to charge higher audit fees as cost compensation. The market value book ratio is $\mathrm{Mb}$. The significance level of $\%$ is significantly positively correlated with audit pricing, indicating that when the market value of the enterprise is higher than the book value, the risk may be included, and the auditor will also charge a higher audit fee; the asset-liability ratio Level and Audit pricing is not significantly correlated; Loss is significantly positively correlated with audit pricing at a $1 \%$ significance level, and when the company has a loss, the auditor is clearly a higher audit fee was obtained; the Top10 concentration of equity was significantly higher with the audit pricing at the $1 \%$ level of significance, indicating 
that the equity is more concentrated, and the "one big share" phenomenon that may occur will affect the company's major business decisions and Financial policy. Empirical evidence shows that auditors also do charge higher audit fees to obtain risk compensation. Opinion is significantly positively correlated with audit pricing at $1 \%$ significance level, indicating that auditors also charge higher audit fees for companies that issue non-standard audit opinions; Big4 is at $1 \%$ The level of significance is significantly positively correlated with audit pricing, indicating that the Big4 accounting firms do receive an audit fee premium.

\subsection{Robustness Test}

In order to enhance the reliability of the conclusions of this paper, this paper re-assigns other comprehensive income for robustness testing. When other comprehensive income OCI is non-zero, it is assigned a value of 1 , otherwise it is assigned a value of 0 . This paper re-examines the research hypothesis, and the regression results are shown in Table 4.

Table 4. Robustness test.

\begin{tabular}{|c|c|c|}
\hline Variable & Model (1) & Model (2) \\
\hline \multirow[t]{2}{*}{ OCI } & $0.0308^{\star * \star}$ & $0.0855^{\star * *}$ \\
\hline & 3.917 & 3.638 \\
\hline \multirow[t]{2}{*}{ Experience $\times$ OCI } & & $-0.00349^{* *}$ \\
\hline & & -2.471 \\
\hline \multirow{2}{*}{ Experience } & $0.00248^{\star * *}$ & $0.00432^{* * *}$ \\
\hline & 3.095 & 3.949 \\
\hline \multirow[t]{2}{*}{ ROA } & 0.0567 & 0.0529 \\
\hline & 0.797 & 0.744 \\
\hline \multirow[t]{2}{*}{$\operatorname{Rec}$} & 0.0723 & 0.0751 \\
\hline & 1.305 & 1.355 \\
\hline \multirow[t]{2}{*}{ Inv } & 0.0223 & 0.0236 \\
\hline & 0.565 & 0.597 \\
\hline \multirow[t]{2}{*}{ Cur } & -0.000360 & -0.000453 \\
\hline & -0.268 & -0.337 \\
\hline \multirow[t]{2}{*}{ Size } & $0.343^{* * *}$ & $0.344^{* * *}$ \\
\hline & 48.43 & 48.48 \\
\hline \multirow[t]{2}{*}{$\mathrm{Mb}$} & $0.0103^{\star * \star}$ & $0.0104^{\star * *}$ \\
\hline & 5.521 & 5.572 \\
\hline \multirow[t]{2}{*}{ Level } & -0.00989 & -0.0117 \\
\hline & -0.351 & -0.416 \\
\hline \multirow[t]{2}{*}{ Loss } & $0.0339^{* \star *}$ & $0.0338^{\star * \star}$ \\
\hline & 3.289 & 3.279 \\
\hline
\end{tabular}




\section{Continued}

\begin{tabular}{ccc}
\hline Top10 & $0.168^{* * *}$ & $0.169^{* * *}$ \\
& 5.177 & 5.209 \\
Opinion & $0.0751^{* * *}$ & $0.0757^{* * *}$ \\
& 4.589 & 4.622 \\
Big4 & $0.156^{* * *}$ & $0.155^{* * *}$ \\
& 5.123 & 5.088 \\
Constant & $6.055^{* * *}$ & $6.018^{* * *}$ \\
& 38.93 & 38.52 \\
Year & Yes & Yes \\
Industry & Yes & Yes \\
R-squared & 0.538 & 0.538 \\
Observations & 13,978 & 13,978 \\
\hline
\end{tabular}

T-statistics in parentheses: ${ }^{* *} \mathrm{p}<0.01,{ }^{* *} \mathrm{p}<0.05,{ }^{*} \mathrm{p}<0.1$.

This paper still finds that there is a significant positive correlation between other comprehensive income and audit pricing. There is a significant positive correlation between auditor's practice experience and audit pricing, and the auditor's practice experience will indeed weaken the positive correlation between other comprehensive income and audit pricing. The relationship verified the research hypotheses $\mathrm{H} 1, \mathrm{H} 2$ and $\mathrm{H} 3$ proposed in this paper, and the research results are robust.

\section{Conclusions and Prospects}

\subsection{Research Conclusions}

Based on the theory of auditing demand and the theory of principal-agent, this paper takes the data of 2011-2017 of listed companies in China as a sample, empirically tests the relationship between other comprehensive income and the experience of auditors and audit pricing, and further explores the impact of auditor practice experience on the relationship between other comprehensive income and audit pricing.

The empirical results of this paper find that other comprehensive incomes are significantly positively correlated with audit pricing. Since other comprehensive income contains more complex and uncertain components, and many components adopt fair value measurement model, it contains many subjective estimation of the management. It is estimated that auditors need to invest more audit resources and face higher audit risks, so the auditors charge higher audit fees. At the same time, the richer the auditor's practice experience, the higher the audit fees. That is, there is an audit premium. The longer the auditor's practice period, the audit experience he has gained will be more professional and effective in the execution of the audit business, and the high-quality audit service signal will be transmitted to the audit client, thus obtaining a higher audit fee; this paper fur- 
ther discovers the audit. The professional experience of the division will significantly weaken the positive relationship between other comprehensive income and audit pricing. For the audit of other comprehensive income matters, the auditors with rich experience will have a more professional analysis, and the assessment of audit risk will be more reasonable. The development of the work and the implementation of the audit procedures are also more targeted, thus reducing the positive impact of other comprehensive income on audit pricing to a certain extent.

\subsection{Research Deficiency and Outlook}

This paper proves the impact of other comprehensive income on audit pricing through empirical research, and focuses on the absolute value of the current amount of other comprehensive income. However, from the perspective of other comprehensive income components and specific projects, it contains many potential impacts of economic business activities on the future of the company. Different components and projects contain different information, the hidden content of the information and the risks involved. There are large differences in size, so the impact on auditor risk assessment is completely different. Limited to time cost and data accessibility, this paper does not provide an in-depth analysis of the impact of other components of the comprehensive income and specific projects on audit pricing, but discusses and analyzes it in general. In future research, we can further discuss and analyze the impact of other comprehensive income components and specific projects on audit pricing, and enrich relevant theoretical research.

\section{Conflicts of Interest}

The author declares no conflicts of interest regarding the publication of this paper.

\section{References}

[1] Dhaliwal, D., Subramanyam, K.R. and Trezevant, R. (1999) Is Comprehensive Income Superior to Net Income as a Measure of Firm Performance. Journal of Accounting \& Economics, 26, 43-67. https://doi.org/10.1016/S0165-4101(98)00033-0

[2] Simunic, D.A. (1980) The Pricing of Audit Serbices: Theory and Evidences. Journal of Accounting Research, 18, 161-190. https://doi.org/10.2307/2490397

[3] Francis, J.R. (1984) The Effect of Audit Firm Size On Audit Prices: A Study of the Australian Market. Journal of Accounting and Economics, 6, 133-151. https://doi.org/10.1016/0165-4101(84)90010-7

[4] Firth, M. (1985) An Analysis of Audit Fees and Their Determinants in New Zealand. Auditing: A Journal of Practice \& Theory, 4, 23-37.

[5] Bell, T.B., Landsman, W.R. and Shackelford, D.A. (2010) Auditors' Perceived Business Risk and Audit Fees: Analysis and Evidence. Journal of Accounting Research, 39, 35-43. https://doi.org/10.1111/1475-679X.00002

[6] Abbott, L.J., Parker, S. and Peters, G.F. (2006) Earnings Management, Litigation Risk, and Asymmetric Audit Fee Responses. Auditing. A Journal of Practice \& 
Theory, 25, 85-98. https://doi.org/10.2308/aud.2006.25.1.85

[7] Carcello, J.V., Hermanson, D.R., Neal, T.L., et al. (2002) Board Characteristics and Audit Fees. Contemporary Accounting Research, 19, 365-384. https://doi.org/10.1506/CHWK-GMQ0-MLKE-K03V

[8] Craswell, A.T., Francis, J.R. and Taylor, S.L. (1995) Auditor Brand Name Reputations and Industry Specializations. Journal of Accounting and Economics, 20, 297-322. https://doi.org/10.1016/0165-4101(95)00403-3

[9] Defond, M.L., Francis, J.R. and Wong, T.J. (2000) Auditor Industry Specialization And Market Segmentation: Evidence from Hong Kong. Auditing: A Journal of Practice \& Theory, 19, 49-66. https://doi.org/10.2308/aud.2000.19.1.49

[10] Carson, E. and Fargher, N. (2007) Note on Audit Fee Premiums to Client Size and Industry Specialization. Accounting \& Finance, 47, 423-446. https://doi.org/10.1111/j.1467-629X.2007.00213.x

[11] Simon, D.T. and Francis, J.R. (1988) The Effects of Auditor Change on Audit Fees: Tests of Price Cutting and Price Recovery. Accounting Review, 63, 255-269.

[12] Song, Y.Z. and Yin, D.Q. (2005) Change of Accounting Firms, Audit Fees and Audit Quality-Evidence from Listed Companies Changing Accounting Firms. Audit Research, No. 2, 72-77.

[13] Landsman, W., Miller, B., Peasnell, K. and Yeh, S. (2011) Do Investors Understand Really Dirty Surplus? The Accounting Review, 86, 237-258.

https://doi.org/10.2308/accr.00000014

[14] Goncharov, I. and Hodgson, A. (2011) Measuring and Reporting Income in Europe. Journal of Accounting and Economics, 29, 1-51.

[15] Cheng, A., Cheung, J. and Gopalakrishnan, V. (1993) On the Usefulness of Operating Income, Net Income, and Comprehensive Income in Explaining Equity Returns. Accounting and Business Research, 23, 195-203. https://doi.org/10.1080/00014788.1993.9729879

[16] Barton, J., Hansen, T.B. and Pownall, G. (2010) Which Performance Measures Do Investors around the World Value the Most-And Why? Accounting Review, 85, 753-789. https://doi.org/10.2308/accr.2010.85.3.753

[17] Biddle, G.C. and Choi, J.H. (2006) Is Comprehensive Income Useful? Journal of Contemporary Accounting \& Economics, 2, 1-32. https://doi.org/10.1016/S1815-5669(10)70015-1

[18] Kanagaretnam, K., Mathieu, R. and Shehata, M. (2009) Usefulness of Comprehensive Income Reporting in Canada. Journal of Accounting \& Public Policy, 28, 349-365. https://doi.org/10.1016/j.jaccpubpol.2009.06.004

[19] Hirst, D.E. and Hopkins, P.E. (1998) Comprehensive Income Reporting and Analysts' Valuation Judgments. Journal of Accounting Research, 36, 47-75. https://doi.org/10.2307/2491306

[20] Maines, L.A. and Mcdaniel, L.S. (2000) Effects of Comprehensive-Income Characteristics on Nonprofessional Investors' Judgments: The Role of Financial-Statement Presentation Format. Accounting Review, 75, 179-207. https://doi.org/10.2308/accr.2000.75.2.179

[21] Khan, S. and Bradbury, M. (2015) The Volatility of Comprehensive Income and Its Association with Market Risk. Accounting and Finance, 56, 727-748. https://doi.org/10.1111/acfi.12108

[22] Libby, R. and Frederick, D.M. (1990) Experience and the Ability to Explain Audit Findings. Journal of Accounting Research, 28, 348-367. 
https://doi.org/10.2307/2491154

[23] Han, W.F. (2016) Auditor's Personal Experience, Industry Expertise and Audit Fees. Accounting and Economic Research, No. 6, 91-108.

[24] Wang, X., Wang, Y., Yu, L., et al. (2016) Personal Experience and Audit Quality of Auditors. Accounting Research, No. 9, 75-81.

[25] Zhang, J. and Wei, C. (2016) Legal Risk, Practice Experience and Audit Quality. Audit Research, No. 1, 85-93.

[26] Huang, H.W. and Lin Steve, K. (2016) Raghunandan. The Volatility of Other Comprehensive Income and Audit Fees. Accounting Horizons, 30, 195-210. https://doi.org/10.2308/acch-51357

[27] Pan, W. and Xin, Q. (2003) On Audit Contract and Audit Quality-Realistic Thinking Based on Incomplete Contract Theory. Audit Research, No. 5, 38-41.

[28] Cai, C. and Xie, L. (2015) Executive Audit Background, Earnings Management and Abnormal Audit Fees. Accounting Research, No. 3, 72-95.

[29] Yang, K. (2016) Other Comprehensive Income, Information Transparency and Earnings Management. Journal of Central University of Finance and Economics, No. 8, 65-73.

[30] Hambrick, D.C. and Mason, P.A. (1984) Upper Echelons: The Organization as a Reflection of Its Top Managers. Social Science Electronic Publishing, 9, 193-206.

[31] Zhang, J., Chen, Y. and Wu, H. (2005) Analysis of the Impact of Risk Factors on the Listing Audit Fees-The Data of the Shanghai Stock Exchange 2003. Audit Research, No. 4, 34-38.

[32] Shelton, S.W. (1999) The Effect of Experience on the Use of Irrelevant Evidence in Auditor Judgment. Accounting Review, 74, 217-224.

https://doi.org/10.2308/accr.1999.74.2.217 